\title{
Using Audio-Visual-based Electronic Media in Softball Learning Literature Review
}

\author{
Povian Yona Mahatmasari ${ }^{1 *}$, Bernadeta Suhartini ${ }^{1}$ \\ ${ }^{I}$ Faculty of Sport Sciences, Universitas Negeri Yogyakarta, Yogyakarta, Indonesia \\ ${ }^{*}$ Corresponding author.Email: povianyona.2020@student.uny.ac.id
}

\begin{abstract}
Media is one of the infrastructures used to provide material to produce a maximum learning. Media is used in every lesson, including physical education on the material of a small ball game, namely softball. The problem is the lack of media used in providing softball learning in school. In the last 7-10 years, the media used to provide softball learning is audio visual-based electronic media. This electronic media is considered effective to deliver softball learning materials in school. Material and Methods: This study was a literature review which aimed to reveal the advantages and lack of audio visual-based electronic media used in physical education learning on softball material in school. Result: This study had resulted that audio-visual-based electronic media had become an important factor in the success of softball learning. Conclusion: This study implied that it is important that to establish and apply a media of learning should be based on the needs of a learning.
\end{abstract}

Keywords: Media, Learning, Softball, Physical Education Learning, Audio Visual, Electronic Media

\section{INTRODUCTION}

Softball is a team sport and included in the category of small ball games in physical education learning. Oktariyana and Muharrami explain that softball is a small ball game that is included in the orientation of the field of physical education at student and school level [1]. Nainggolan also explains that softball is a game in the hitting ball group which is played by nine people as the batting team and nine people as the guard team. It is played by 9 players and is played in 7 innings, where each team gets a turn to be a defender and attack for 7 times [2]. Three people (player) are prepared for substitution when the defending team managed to turn off the players from the attacking team [3]. The group of guard positions in softball games is divided into two groups, namely infield and outfield. The infield guard positions are Pitcher, Cachter, First Baseman, Second Baseman, Third Baseman, and Short Stop, while the outfield guard positions are Center Fielder, Left Fielder, and Right Fielder [4].

Softball is also a new sport familiar with the Indonesian. In addition, softball is also one of Indonesia's achievement sports that has been started to popular in recent years [5]. Although softball is a popular sport and is included in physical education learning, there are still many shortcomings and difficulties to implement it in schools. Budhiarta explains that the difficulty in implementing softball learning is due to the relatively small amount of time to apply and inadequate learning tools [6]. As well as the media used in softball learning is relatively limited, the lack of learning media used in the application of softball learning in schools has also indicated the lack of modifications to softball games made by teachers [7]. Using media in learning becomes a support in the delivery of information and messages that can stimulate interest, attention, feeling, willingness, and thoughts in learning activities. Widiastuti reveals that the lack of infrastructure and media used in the delivery of physical education learning become an obstacle in the success of softball learning, so that the results obtained were not optimal [8].

Popularity and inclusion in physical education learning requires a good delivery in softball. Moreover, there are still some obstacles in the delivery of learning; that is the use of media in delivering softball learning. The media in the field is divided into two kinds, namely electrochemical-based media and non-electronic media 
primarily used in softball sports. Electronic media in the form of a prototype reaction training tool that uses signals can provide maximum results in learning to throw balls on softball players [9]. The use of electronic devices can support learning and keep up with the times. With the existence of electronic media in softball games, it can help the process of learning activities in order that students can understand the material and basic techniques of softball, especially the ability to hit. Hitting exercises are more effective by the use of the media, and one of the media is using an application that can see how the gamma waves are made when hitting [10]. In addition to using electronic media, some studies state that visual media is one of the effective media can support the success of softball games and learning itself [11]. Therefore, this study aimed to examine the strengths and weaknesses of the media used to deliver learning material.

\section{METHODS}

This research was a type of literature review, which means it examined the results of previous studies that reveal about electronics that are used both in the delivery of softball learning in schools. This study examined the strengths and weaknesses of the media used to deliver the material. Furthermore, the literature review research included in this study was the type of qualitative descriptive research. The data in this study were obtained through documents from previous research which were collected by collecting and analyzing document file articles from scientific journals that have been published both nationally and internationally. This study examined 15 articles on the delivery of learning through electronic media in the use of delivery of physical education learning on softball discussions in schools

\section{RESULTS AND DISCUSSION}

\subsection{Summary of Previous Research}

This study was literature review that purposed to examine the strengths and weaknesses of the media used to deliver learning material. The data in this study were 15 journal articles that discussed audio visual-based electronic media in physical education learning on softball discussion. The fifteen journal articles were in the coverage of last seven years of publication from 2013 to 2020 . This categorization was used to identify a novel aspect within years. This study has resulted variety of differences in fifteen journal articles by their methods

focuses.

Table 1. List of journal articles and their focuses

\begin{tabular}{|c|c|c|c|}
\hline Author/Year & Focus & Methods & Results \\
\hline $\begin{array}{l}\text { Ageng Permadi } \\
(2015)\end{array}$ & $\begin{array}{l}\text { The Effectiveness of } \\
\text { Learning Using } \\
\text { Video Media and } \\
\text { Mirror Media on } \\
\text { Learning Outcomes } \\
\text { to Hit Softball }\end{array}$ & Experimental method & $\begin{array}{l}\text { The results of the media feasibility test of this module } \\
\text { based on the results of the material expert } \\
\text { questionnaire are } 87.5 \% \text { (very good), the results are. } \\
\text { The media expert's trial questionnaire was } 93.2 \% \\
\text { (very good), the results of the individual trial } \\
\text { questionnaire were } 85 \% \text { (very good), the results of } \\
\text { the small group trial questionnaire were } 86 \% \text { (very } \\
\text { good), and the results of the large group trial } \\
\text { questionnaire were } 91.5 \% \text { (very good). It can be } \\
\text { concluded that the development of learning videos is } \\
\text { feasible and can help the process }\end{array}$ \\
\hline $\begin{array}{l}\text { Oktariyana, } \\
\text { Wan Ahmad } \\
\text { Rizki } \\
\text { Muharrami } \\
(2018)\end{array}$ & $\begin{array}{l}\text { Throwing } r \text { and } \\
\text { Catching Skills in } \\
\text { Audio Visual-Based } \\
\text { Softball }\end{array}$ & $\begin{array}{l}\text { An experimental } \\
\text { method, with the } \\
\text { research design of One- } \\
\text { Shot Case Study }\end{array}$ & $\begin{array}{l}\text { The results of the catch-and-shoot test at the South } \\
\text { Tangerang softball club altras baseball were the most } \\
\text { dominant category with the highest percentage of } \\
40 \% \text {. The results of the catch-and-shoot test at } \\
\text { baseball softball club altras which are categorized as } \\
\text { Very Good are } 40 \% \text {, Good category is } 20 \% \text {, Enough } \\
\text { is } 26 \% \text {, Less with a percentage of } 7 \% \text {, while Less } \\
\text { Once is } 7 \%\end{array}$ \\
\hline $\begin{array}{l}\text { Umar } \\
\text { Nurzaman, } \\
\text { Sulaiman, Agus } \\
\text { Widodo Suripto } \\
\text { (2017) }\end{array}$ & $\begin{array}{l}\text { Improving Learning } \\
\text { Outcomes of Basic } \\
\text { Throwing } \\
\text { Movements with } \\
\text { Audio Visual Media }\end{array}$ & Action Research method & $\begin{array}{l}\text { The results of the activities showed that in general the } \\
\text { training was running smoothly. Mastery of students } \\
\text { and physical education teachers on the basic } \\
\text { techniques of playing softball is quite good. The } \\
\text { responses of the participating students and teachers }\end{array}$ \\
\hline
\end{tabular}




\begin{tabular}{|c|c|c|c|}
\hline & & & $\begin{array}{l}\text { were positive and they were very enthusiastic about } \\
\text { participating in the training. The obstacle } \\
\text { encountered in the implementation of the training } \\
\text { was the lack of time to practice playing softball }\end{array}$ \\
\hline $\begin{array}{l}\text { Arifin Ika } \\
\text { Nugroho, Andi } \\
\text { Muhammad } \\
\text { Fadlih (2019) }\end{array}$ & $\begin{array}{l}\text { The Effect of Softball } \\
\text { Basic Learning } \\
\text { Resources on the } \\
\text { Cognitive Ability }\end{array}$ & $\begin{array}{l}\text { A quasi-experimental } \\
\text { method }\end{array}$ & $\begin{array}{l}\text { Based on this comparison, it can be concluded that, } \\
\text { Ha or alternative hypothesis one which states that: } \\
\text { there is an influence of multimedia-based softball } \\
\text { basic learning resources on PJKR students at } \\
\text { Musamus University, Merauke }\end{array}$ \\
\hline $\begin{array}{l}\text { Eka Fitri Novita } \\
\text { Sari, Dwi } \\
\text { Susanti,Yusma } \\
\text { wati and Slamet } \\
\text { Maulana (2021) }\end{array}$ & $\begin{array}{l}\text { Implementation Of } \\
\text { DVD Softball } \\
\text { Technique Integrated } \\
\text { with Momentum and } \\
\text { Impulses Material } \\
\text { Towards Softball } \\
\text { Hitting Skill and } \\
\text { Improvement of } \\
\text { Physics Knowledge }\end{array}$ & $\begin{array}{l}\text { A quasi-experimental } \\
\text { method }\end{array}$ & $\begin{array}{l}\text { Based on the results and discussion, it can be } \\
\text { concluded that the use of instructional DVD media on } \\
\text { the technique of hitting a softball ball that is } \\
\text { integrated with the concept of momentum and } \\
\text { impulse material has a great influence on the quality } \\
\text { of softball hitting skills and increasing knowledge } \\
\text { about momentum and impulses. }\end{array}$ \\
\hline $\begin{array}{l}\text { Saida } \quad \text { Ulfa } \\
(2016)\end{array}$ & $\begin{array}{l}\text { Increasing motivation } \\
\text { for movement in } \\
\text { softball games with } \\
\text { modified tools }\end{array}$ & $\begin{array}{ll}\text { Classroom } & \text { action } \\
\text { research (CAR) }\end{array}$ & $\begin{array}{l}\text { Technological developments change the learning } \\
\text { paradigm that has changed the way children learn } \\
\text { And interact with the environment. Nowadays, } \\
\text { interaction with technology starts from humans are } \\
\text { born into the world. So that. This causes the } \\
\text { opportunity for early childhood to recognize literacy } \\
\text { and numeracy through technology is getting bigger }\end{array}$ \\
\hline $\begin{array}{l}\text { Arifin Ika } \\
\text { Nugroho, Andi } \\
\text { Muhammad } \\
\text { Fadlih (2019) }\end{array}$ & $\begin{array}{l}\text { Development of } \\
\text { Media Strike Zone } \\
\text { for Pitching Learning } \\
\text { Process on Softball }\end{array}$ & $\begin{array}{l}\text { Research and } \\
\text { Development (R\&D) }\end{array}$ & $\begin{array}{l}\text { The results of the data can be concluded that: (1) The } \\
\text { learning model of softball throwing and catching } \\
\text { skills using learning media in high school can be } \\
\text { developed and applied in learning and extracurricular } \\
\text { activities at school, (2) from the model there is } \\
\text { evidence of an increase by showing the results of } \\
\text { testing the pretest and posttest data. there is a } \\
\text { significant difference between before and after the } \\
\text { model treatment }\end{array}$ \\
\hline $\begin{array}{l}\text { Mudjihartono } \\
\text { Mudjihartono, } \\
\text { Wahyudianto } \\
\text { Wahyudianto, } \\
\text { Agus Gumilar* } \\
(2019) \text {. }\end{array}$ & $\begin{array}{lr}\text { Application } & \text { Of } \\
\text { Learning } & \text { Softball } \\
\text { Using } & \text { Modified } \\
\text { Glove and } & \text { Ball for } \\
\text { Developing } & \text { Basic } \\
\text { Movement } & \text { Skills } \\
\text { Throwing } & \text { and } \\
\text { Catching } & \end{array}$ & $\begin{array}{lr}\text { Classroom } & \text { action } \\
\text { research } & \text { (CAR) by } \\
\text { Kurtlewin } & \end{array}$ & $\begin{array}{l}\text { The results showed that (1) the resulting model } \\
\text { product was in the form of a softball throwing } \\
\text { technique module for beginners, (2) the model } \\
\text { product of a softball throw and catch technique was } \\
\text { declared worthy of being used as a reference or } \\
\text { reference for teachers, students and softball coaches } \\
\text { based on the results. assessment of material experts } \\
3.8 \text { and expert softball coaches } 4.3 \text { with the "very } \\
\text { good" category. (3) the effectiveness of the product is } \\
\text { proven by improving the throwing and catching skills } \\
\text { of softball sports by achieving an average score of } \\
65.46 \text { for pretest and } 79.53 \text { for posttest. }\end{array}$ \\
\hline $\begin{array}{l}\text { Febi Warta Nur } \\
\text { Ani, Utari Dewi } \\
(2016)\end{array}$ & $\begin{array}{l}\text { Perceptions of aging } \\
\text { among older women } \\
\text { softball players }\end{array}$ & A quasi experiment & $\begin{array}{l}\text { Results mastery of basic techniques softball game } \\
\text { students also increased, namely by } 35 \% \text { for basic } \\
\text { technique throwing the ball, } 50 \% \text { to the basic } \\
\text { techniques of capture, and } 60 \% \text { to the basic } \\
\text { techniques of hit plastic balls. It can be concluded } \\
\text { that the interest and motivation of students in the } \\
\text { learning following the softball game can be improved } \\
\text { through the game of baseball and plastic balls. } \\
\text { Keywords: Motivation, softball, modification, aids } \\
\text { baseball and plastic balls }\end{array}$ \\
\hline
\end{tabular}




\begin{tabular}{|c|c|c|c|}
\hline $\begin{array}{l}\text { Jajat Darajat } \\
\text { Kusumah } \\
\text { Negara, Sufyar } \\
\text { Mudjianto, } \\
\text { Astri } \\
\text { Budikayanti, } \\
\text { Adhitya } \\
\text { Nugraha (2021) }\end{array}$ & $\begin{array}{l}\text { The Effect of Media } \\
\text { Professionalization } \\
\text { on Cognitive } \\
\text { Neurodynamics } \\
\text { During Audivisual } \\
\text { Cuts }\end{array}$ & Experiment & $\begin{array}{l}\text { We found that media professionals decreased their } \\
\text { blink rate after the cuts, suggesting that they can } \\
\text { better manage the loss of visual information that } \\
\text { blinks entail by sparing them when new visual } \\
\text { information is being presented. Cuts triggered similar } \\
\text { activation of basic brain processing in the visual } \\
\text { cortex of the two groups, but different processing in } \\
\text { medial and frontal cortical areas, where media } \\
\text { professionals showed a lower activity. Effective brain } \\
\text { connectivity occurred in a more organized way in } \\
\text { media professionals-possibly due to a better } \\
\text { communication between cortical areas that are } \\
\text { coordinated for decoding new visual content after } \\
\text { cuts }\end{array}$ \\
\hline
\end{tabular}

\subsection{Explanation of Subject Matter}

\subsubsection{Audio-Visual-based Electronic Media in Physical Education Learning}

Media is one of the facilities and infrastructures used to support the success of learning. Audio-visual-based electronic media is one of the supporting factors in the success of physical education learning. The use of video in the learning process can be used for cognitive, psychomotor, and affective purposes. Adi et al mention that media is one of the important things in physical education learning [12]. The delivery of learning used by technology-based and audio visual physical education teachers is considered effective to support students' success in learning [13] . Saskia et al explained that the implementation of the TGT method of cooperative learning through audio-visual (video) media had a significant effect on increasing jump rope skills in physical education learning [14]. In addition, Olmedo et al explained that there was a statistically significant difference between the scores of the flipped classroom and the traditional group, as well as between the mixed and traditional groups [15] . Therefore, using web-based audio-visual content in the classroom may be a useful methodology.

\subsubsection{Advantages of Audio-Visual-based Electronic Media in Softball Learning}

Audio-visual-based electronic media, such as DVD is an important factor in the success of softball learning, especially in throwing skills. This media is able to visualize a good throwing movement, so that students are able to see and apply it correctly [16]. The use of DVD as a media in learning on the technique of hitting the softball is integrated with the concept of momentum and impulse material that has a great influence on the quality of softball hitting skills and increases knowledge on momentum and encouragement, so that DVD media is considered benefit over other media due to following technological developments applied in learning [17]. Juditya and Agusni explained that the advantage of audio-visual media is its sound and image element [18]. This type of media has better capabilities, because it includes both types of media, namely audio and visual media. To be more effective in the delivery of teaching materials, it needs to be supported by tools that can be used efficiently and effectively on softball learning outcomes.

Furthermore, the development of this learning video can be well received by students, so that teachers can clarify and deliver the material to improve learning outcomes [19] . By using audio-visual media, students are also expected to be able to understand and practice the basic movements of throwing by hand and foot movements as well as by good and correct body position. Besides, they can learn with a different scene to avoid bored during learning [20]. The use of video in softball learning helps students understand the image area of the strike zone, so that students who do pitching are easier to direct their throws well [21]. Mudjihartono et al confirmed that the use of multimedia in softball learning can improve learning abilities. The advantage of using multimedia is that it can increase students' enthusiasm in learning [22].

\subsubsection{Weaknesses}

The use of audio-visual-based electronic media in softball learning has advantages in learning and technology mastering. Even though it has several advantages, the use of this media also has disadvantages. [22] argue that the use of video can improve the ability or "throw" during the softball learning [23]. However, in its application, this media should be adapted to the abilities and conditions of students, so that students can easily absorb learning materials well. Rihatno and Gunawan explained that audio-visual-based electronic media are less able to display the details of objects that are presented perfectly and it requires an expensive and complex equipment to use [25]. Besides, teachers are required to understand how to use the media to get maximum learning outcomes. As result, there should be an extra 
supervision, so that students are able to maximize their abilities through video media.

Apart from previous disanvantage, Puspitasari also revealed that the weakness of electronic media was requiring a special place/spot for note-taking, because electronic modules cannot be scribbled arbitrarily and not all students can use the module [26]. Some of the weaknesses that can arise from learning to use electronic media are that it allows users to be exposed to electromagnetic fields originating from the use of electronic media from these devices, toxins from batteries, and so on [27]. Wyant explains that the use of audio-visual-based media technology requires special attention before its application in learning. Besides, sometimes teachers are difficult to utilize it due to limited knowledge on electronic media [28].

\section{CONCLUSION}

The media had several advantages and disadvantages in its application. Audio-visual-based electronic media had become an important factor in the success of softball learning; apart from its weaknesses that had been revealed in this study. However, this media was useful and effective to improve softball learning achievement in physical education. Any supervision and preparation should be taken into account to avoid ineffectiveness of the media utilization. There is a necessary to conduct a future research on the application of audio-visual-based electronic media in softball learning as well as to evaluate how it is prepared and resulted a particular outcome.

\section{REFERENCES}

[1] Oktariyana, Muharrami War. Model Latihan Teknik Lempar Tangkap Cabang Olahraga Softball Pada Pemula. J Penjaskesrek. 2018;5(1).

[2] Nainggolan AP. Modifikasi Alat Bantu Pembelajaran Melempar Menangkap Dan Memukul Bola Dalam Hasil Belajar Permainan Softball. J UIN Surabaya. 2014;(1):36-7.

[3] Permadi A. Upaya Meningkatkan Hasil Pukulan Swing dalam Permainan Softball Menggunakan Metode Resipokal. J Pedagog Keolahragaan. 2015;01(01):29-43.

[4] Darisman EK, Ismawandi BP, Sriningsih WD. Hubungan Antara Mental Toughness Dan Competitive Anxiety Atlet UKM SOFTBALL Universitas PGRI Adi Buana Surabaya. J Ilm ADIRAGA. 2020;6(2):10-24.

[5] Isdianto FA, Ramadin TY. Indonesia BaseballSoftball Center. J Tingkat Sarj Bid Senirupa dan Desain [Internet]. 2014;1:1-7. Available from: http://jurnal-
s1.fsrd.itb.ac.id/index.php/interior/article/viewFile/ $403 / 352$

[6] Danu Budhiarta IM. Pelatihan Softball bagi Siswa dan Guru Penjasorkes di Kota Negara. Widya Laksana. 2017;6(1):30-7.

[7] Pranyoto FS. Survei Kelayakan Bola Reaksi Sebagai Saran Pembelajaran Pendidikan Jasmani Oleh Guru Sekolah Dasar Di Kabupaten Sleman Feasibility Survey Of Reaction Ball As Teaching Advice For Basic Education By Primary School Teachers In Sleman District. JSH J Sport Heal. 2020;2(1):1-5

[8] Widiastuti W. Mengatasi Keterbatasan Sarana Prasarana Pada Pembelajaran Pendidikan Jasmani [Overcoming Facilities Limitations Affecting Physical Education Learning Activities]. Polyglot J Ilm. 2019;15(1):140.

[9] Rahmat AA, Rohyana A. Pengembangan Prototipe Alat Bantu Latihan Reaksi Yang Mengunakan Sinyal Lampu Dan Bunyi Terhadap Kecepatan Lemparan Atas Softball. JUARA J Olahraga. 2020;5(3).

[10] Negara JDK, Mudjianto S, Budikayanti A, Adhitya Nugraha PP. The effect of gamma wave optimization and attention on hitting skills in softball. Int J Hum Mov Sport Sci. 2021;9(1):1039.

[11] Saputro AK, Susilo. Model Pembelajaran Lempar Tangkap Softballmenggunakan Media Pembelajaran. J PENJAKORA. 2019;6(2):75-81.

[12] Adi S, Soenyoto T, Sulaiman. Implementasi Media dalam Proses Belajar Mengajar Fisik, Olahraga, dan Mata Pelajaran Pendidikan Kesehatan. J Phys Educ Sport [Internet]. 2018;7(1):13-21. Available from:

https://journal.unnes.ac.id/sju/index.php/jpes/articl e/view/19740

[13] Batanero JMF-, Rueda MM-, U JF-C, Martinez IG-. Impact of the information and communication technologies on the education of students with down syndrome: A bibliometric study (20082018). Eur J Educ Res. 2020;9(1):79-89.

[14] Saskia S, Mahendra A, Samini N. Implementasi Model Cooperative Learning Metode TGT Melalui Media Audiovisual Dalam Pembelajaran Aktivitas Ritmik Lompat Tali Di Sekolah Dasar. TEGAR J Teach Phys Educ Elem Sch. 2018;2(1):15.

[15] Jimenez-Olmedo JM, Penichet-Tomas A, Pueo B, Carbonell-Martinez JA. the Use of Web-Based Audiovisual Lectures in Classroom and Flipped Learning. EDULEARN17 Proc. 2017;1(July):3927-33.

[16] Law B, Post P, Jenny O, McCullagh P. Video- 
based observation in sport: From "forgotten" to ubiquitous. J Sport Psychol Action [Internet]. 2018;9(4):260-70. Available from: https://doi.org/10.1080/21520704.2018.1513962

[17] Sari EFN, Susanti D, Yusmawati, Maulana S. Implementation of DVD softball technique integrated with momentum and impulses material towards softball hitting skill and improvement of physics knowledge. 4TH Int Conf Math Sci Educ 2020 Innov Res Sci Math Educ Disruptive Era. 2021;2330:020029.

[18] Juditya S, Agusni D. Keterampilan Lempar Tangkap dalam Olahraga Softball Berbasis Audio Visual. J Olahraga. 2018;4(1):16-23.

[19] Ani FWN, Dewi U. Pengembangan Video Pembelajaran pada Mata Kuliah T/P. Softball Materi Teknik Dasar Permainan Softball untuk Mahasiswa S1 Pendidikan Kepelatihan Olahraga Semester IV di Universitas Negeri Surabaya. J Mhs Teknol Pendidik. 2015;6(2):1-9.

[20] Irsyada R. Development of Media Strike Zone for Pitching Learning Process on Softball. J Phys Educ Heal Sport. 2019;6(1):23-6.

[21] Mudjihartono M, Wahyudianto W, Gumilar A. Application of Learning Softball Using Modified Glove and Ball for Developing Basic Movement Skills Throwing and Catching for High School Students. Adv Heal Sci Res. 2019;11(Icsshpe 2018):259-61.

[22] Dwiantika IS, Kristiyandaru A. Pengaruh Penggunaan Media Audio Visual ( Video ) Terhadap Ketepatan Lemparan (Throwing ) SoftbalL ( Studi pada siswa peserta ekstrakurikuler softball SMK Ketintang Surabaya ). J Pendidik Olahraga dan Kesehat. 2014;2(2):453-6.

[23] Rihatno T, Tobing SRAL. Pengembangan Model Latihan Kekuatan Otot Lengan Pada Cabang Olahraga Softball. Gladi J Ilmu Keolahragaan. 2019;10(1):1-14.

[24] Rihatno T, Gunawan VS. Efektifitas Pembelajaran Menggunakan Media Video Dan Media Cermin Terhadap Hasil Belajar Memukul Bola Softball. J Pendidik Olahraga [Internet]. 2014;3(1):74-82. Available from: http://journal.ikippgriptk.ac.id/index.php/olahraga/ article/view/140/137

[25] Andreu-Sánchez C, Martín-Pascual MÁ, Gruart A, Delgado-García JM. The Effect of Media Professionalization on Cognitive Neurodynamics During Audiovisual Cuts. Front Syst Neurosci. 2021;15(January):1-12.

[26] Puspitasari AD. Penerapan Media Pembelajaran Fisika Menggunakan Modul Cetak dan Modul
Elektronik pada Siswa SMA. J Pendidik Fis [Internet]. 2019;7(1):17-25. Available from: http://journal.uin-

alauddin.ac.id/indeks.php/PendidikanFisika\%0ApISSN

[27] Ulfa S. Pemanfaatan teknologi bergerak sebagai media pembelajaran bagi anak usia dini. Edcomtech. 2016;1(1):1-8.

[28] Wyant J, Baek JH. Re-thinking technology adoption in physical education. Curric Stud Heal Phys Educ [Internet]. 2019;10(1):3-17. Available from:

https://doi.org/10.1080/25742981.2018.1514983 